\title{
PENGARUH MODEL DISCOVERY LEARNING TERHADAP KEMAMPUAN BERPIKIR KREATIF SISWA PADA MATA PELAJARAN ILMU PENGETAHUAN ALAM
}

\author{
Dede Salim Nahdi ${ }^{1)}$, Fery Apriadi ${ }^{2)}$ \\ Salimnahdi15@gmail.com ${ }^{1)}$, fery.apriadi@gmail.com ${ }^{2)}$ \\ Universitas Majalengka
}

\begin{abstract}
ABSTRAK
Penelitian ini dilatarbelakangi masih rendahnya kemampuan berpikir kreatif siswa, bertujuan untuk mengetahui pengaruh model discovery learnig terhadap kemampuan berpikir kreatif siswa pada mata pelajaran ilmu pengetahuan alam. Penelitian ini berbentuk kuasi eksperimen dengan sampel 2 kelas yaitu pada SDN Sutawangi II dengan jumlah masing-masing siswa 21 dan 21. Dari dua kelas yang dipilih dalam penelitian ini, salah satunya digunakan sebagai kelas eksperimen yang memperoleh pembelajaran dengan pembelajaran model discovery learning, sedangkan kelas lainnya sebagai kelas kontrol yang pembelajarannya menggunakan pembelajaran konvensional yang terdiri dari 4 pembelajaran. Instrumen penelitian yang digunakan berupa lembar observasi dan tes kemampuan berpikir kreatif. Lembar observasi digunakan untuk mengetahui proses pembelajaran yang dilakukan dikelas eksperimen, tes kemampuan berpikir kreatif yang digunakan berbentuk essay sebanyak 8 butir yang telah diuji validitas dan realibitasnya. Kedua kelompok diberikan pretest untuk mengetahui keadaan awal siswa dan kemudian diberikan posttest. Skor rata-rata kelas eksperimen dan kelas kontrol adalah 60,10 dan 57,33. Skor rata-rata posttest kelas eksperimen dan kelas kontrol 75,52 dan 64,71. Analisis data menggunakan uji t. Data hasil perhitungan perbedaan dua rerata posttest kedua kelas adalah 0,000, nilai signifikansi ini kurang dari 0,05 , maka $H_{0}$ ditolak. Artinya, peningkatan kemampuan berpikir kreatif siswa yang memperoleh model discovery learning secara signifikan lebih baik daripada siswa yang memperoleh pembelajaran konvensional.
\end{abstract}

Kata kunci: Model discovery learning, kemampuan berpikir kreatif. 


\section{Pendahuluan}

Salah satu komponen yang memegang peranan penting dalam meningkatkan mutu sumber daya manusia adalah guru. Guru merupakan pendidik, pembimbing dan pengarah yang memiliki tugas-tugas utama. Tugas utama guru telah tertera pada undang-undang guru dan dosen no. 14 tahun 2005 menyatakan "Pendidik profesional dengan tugas utama mendidik, mengajar, membimbing, mengarahkan, melatih, menilai dan mengevaluasi peserta didik, baik pada jenjang pendidikan usia dini, jalur pendidikan menengah serta di perguruan tinggi".

Salah satu tolak ukur keberhasilan pendidik dalam menyampaikan pembelajaran adalah bila dalam pembelajaran yang dapat dilakukan dapat mencapai hasil yang optimal. Keberhasilan tersebut sangat bergantung pada kemampuan pendidik untuk mengelola proses belajar mengajar. Hal ini memiliki makna bahwa proses belajar mengajar adalah hal yang perlu mendapat perhatian lebih, karena dalam proses belajar mengajar diharapkan terjadi interaksi langsung antara guru dan siswa dan interaksi siswa dengan siswa lain. Untuk itu diperlukan pemilihan strategi pembelajaran yang tepat.

Strategi pembelajaran dapat diartikan sebagai suatu perencanaan yang berisi tentang rangkaian kegiatan yang didesain untuk mencapai tujuan pembelajaran seperti yang diungkapkan oleh Kemp (dalam Sanjaya, 2010: 294) menjelaskan bahwa strategi pembelajaran adalah suatu kegiatan pembelajaran yang harus dikerjakan guru dan siswa agar tujuan pembelajaran dapat dicapai secara efektif dan efisien. Strategi yang baik adalah strategi yang mampu mengubah paradigma pembelajaran menjadi siswa sebagai objek atau sasaran pembelajaran menjadi subyek atau pelaku dari tujuan pembelajaran.

Namun, kenyataannya strategi pembelajaran yang diterapkan oleh para guru saat ini kurang bervariasi. Kebanyakan guru masih menerapkan pembelajaran konvensional. Dalam proses belajar mengajar, kecakapan berpikir terutama berpikir kreatif juga belum ditangani secara sungguh-sungguh oleh para guru disekolah. Hal tersebut tidak sejalan dengan standar pendidikan nasional nomor 19 tahun 2005 menyatakan bahwa "Pembelajaran pada satuan pendidikan secara interaktif, inspiratif, menyenangkan, menantang, memotivasi siswa untuk berperan aktif serta memberikan ruang yang cukup bagi prakarsa, kreativitas dan kemandirian sesuai dengan bakat, minat, perkembangan fisik serta psikologis peserta didik". Berdasarkan fungsi dan tujuan Pendidikan Nasional tersebut kita ketahui bahwa salah satu hasil (output) yang diharapkan dari sebuah proses pendidikan ialah agar para peserta didik menjadi manusia kreatif. Karena tidak dapat dipungkiri, untuk mengantisipasi perkembangan ilmu pengetahuan dan teknologi yang semakin maju, maka perkembangannya menuntut lahirnya manusia-manusia yang kreatif, professional, dan mempunyai kepedulian terhadap masalah-masalah yang timbul dalam masyarakat. Oleh karena itu, pendidikan yang diselenggarakan harus mengarahkan anak didik untuk dapat menjadi kreatif.

Berpikir kreatif merupakan kemampuan atau keterampilan seseorang dalam membuat sesuatu ide atau produk. Hal ini sejalan dengan yang dikemukakan pada kamus oxford Advance Leaner's Dictionary (dalam Sudarma, 2013: 9) menyatakan istilah thingking salah satunya diartikan "idea or opinions about something". Pemikiran itu adalah idea atau opini. Dengan kata lain, orang yang berpikir adalah orang yang memiliki idea atau opini mengenai sesuatu. Kemampuan berpikir sangat erat kaitannya dengan mata pelajaran ilmu pengetahuan alam, Ilmu pengetahuan alam yang sering disingkat dengan IPA merupakan salah satu mata pelajaran pokok dalam kurikulum pendidikan di Indonesia, termasuk pada jenjang sekolah dasar. 
Ilmu pengetahuan alam merupakan usaha manusia dalam memahami alam semesta melalui pengamatan yang tepat pada sasaran serta ilmu yang dapat diintegrasikan dengan kecakapan berpikir terutama berpikir kreatif, sejalan dengan Susanto (2015: 170) pembelajaran sains merupakan pembelajaran berdasarkan prinsip-prinsip, proses yang mana dapat menumbuhkan sikap ilmiah serta kecakapan berpikir.

Berdasarkan hasil pengamatan yang dilakukan peneliti melalui observasi di Kecamatan Jatiwangi tahun ajaran 2014/2015 menunjukkan bahwa terdapat permasalahan di SDN Sutawangi II di kelas IV pada pembelajaran ilmu pengetahuan sosial yakni kurangnya kemampuan berpikir kreatif, disebabkan pembelajaran yang berlangsung cenderung menggunakan pembelajaran konvensional yakni metode ceramah dalam proses pembelajaran.

Berdasarkan penelitian yang dilakukan oleh Khoiri (2013) pada tingkatan menengah pertama diperoleh data tingkat kemampuan berpikir kreatif siswa kelas VII SMP Negeri 4 Kudus tahun pelajaran 2013/2014 sebanyak 2,73 \% berada pada tingkat kemampuan berpikir kreatif yang tinggi, 15, $45 \%$ tingkat kemampuan berpikir kreatif sedang, 46,36 \% tingkat kemampuan berpikir kreatif siswa rendah dan 35,45 \% tingkat kemampuan berpikir kreatif siswa sangat rendah.

Hasil penelitian TIMSS (Trend in Internasional Mathematics andScience Study) yang merupakan penelitian internasional tentang pencapaian siswa kelas IV dan VIII dalam matematika dan sains yang diadakan setiap empat tahun sekali. Hasilnya, dari 45 negara yang yang berpartisipasi dalam TIMSS 2011, Indonesia hanya menempati posisi ke-38. Tentu saja pencapaian siswa-siswa Indonesia ini belum memuaskan bila dibandingkan dengan siswa-siswa dari tiga Negara Asia Tenggara lain yang ikut berpartisipasi dalam TIMSS 2011 seperti Singapura yang berada pada posisi ke-,
Malaysia posisi ke-26 dan Thailand posisi ke-28 (Nahdi, 2015: 14).

Hasil penelitian TIMSS tersebut berkaitan dengan kemampuan berpikir kreatif siswa. Hal ini dikarenakan pada soal-soal yang diujikan dalam TIMSS ada empat jenis domain kognitif, yaitu (1) mengenal fakta dan prosedur, penalaran, (3) menyelesaikan soal rutin, dan (4) menggunakan konsep. Penalaran erat kaitannya dengan kemampuan berpikir kreatif. Pendidikan di Indonesia yang masih kurang mendukung berkembangnya kemampuan berpikir kreatif anak khususnya dalam bidang matematika dan sains.

Hal ini juga dilakukan karena terbatasnya pengetahuan guru tentang pembelajaran inovatif, kurangnya merefleksikan dan secara ktiris atau kreatif dalam menelaah asumsi-asumsi, kesimpulan dan praktik-praktik mengajar sehingga proses pembelajaran dikelas tidak berlangsung optimal sesuai dengan harapan. Seharusnya, pembelajaran seperti itu harus di ubah sesuai dengan perkembangan zaman. Pembelajaran yang sebelumnya berpusat pada guru, harus menuju pusat pembelajaran pada siswa. Dimana peran guru hanya sebagai fasilitator, disainer pembelajaran, dan manager pembelajaran. Agar siswa dan guru lebih aktif terlibat dalam pembelajaran sehingga pembelajaran tidak di anggap menjemukan, tidak menarik, tidak menyenangkan dan juga tidak menakutkan bagi siswa. Sementara itu, peserta didik juga di dorong agar kreatif dalam berinteraksi dengan sesama teman, guru, meteri pelajaran dan segala alat bantu belajar, sehingga hasil pembelajaran dapat meningkat.

Salah satu alternatif yang digunakan untuk mengembangkan kemampuan berpikir kreatif siswa adalah dengan pembelajaran yang memberikan tantangan kepada anak. Penerapan pembelajaran dengan memberikan pengalaman, mendorong siswa untuk memonitor kemampuan dirinya dalam membuat 
perencanaan dan pemantauan terhadap hasil belajar yang terkait tingkat penguasaan materi pembelajaran dan keberhasilan dan menyelesaikan tugastugasnya secara baik. Kemauan belajar yang kuat dan penetapan tujuan belajar akan memacu setiap siswa rajin belajar.

Model discovery learning adalah merupakan model yang digunakan untuk membangun konsep dibawah pengawasan guru. Terdapat langkah-langkah pada discovery learning seperti yang dikemukakan oleh Syah (dalam Selan, 2015) yaitu, stimulation, problem statemen, data collection, data processing, verification and generalization.

Model discovery dapat membantu dalam, (1) merupakan suatu cara untuk mengembangkan cara belajar siswa aktif;

(2) dengan menemukan dan menyelidiki sendiri konsep yang dipelajari, maka hasil yang diperoleh akan tahan lama dalam ingatan dan tidak mudah dilupakan siswa; (3) pengertian yang ditemukan sendiri merupakan pengertian yang betul-betul dikuasai dan mudah digunakan atau ditransfer dalam situasi lain; (4) dengan menggunakan model discovery anak belajar menguasai salah satu model ilmiah yang akan dapat dikembangkan sendiri; (5) siswa belajar berpikir analisis dan mencoba memecahkan problema yang dihadapi sendiri, kebiasaan ini akan ditransfer dalam kehidupan nyata.

\section{Metode Penelitian}

Desain penelitian yang digunakan adalah nonequivalent control group design yang merupakan salah satu model desain Quasi Experiment atau eksperimen semu. Dalam desain ini terdapat dua kelompok yang dipilih, kemudian diberi pre-test untuk mengetahui keadaan awal adakah perbedaan antara kelompok eksperimen ataupun kelompok kontrol dan terakhir diberikan post-test. Di dalam desain ini diperoleh data sebanyak 2 (dua) kali yaitu melakukan model pembelajaran konvensional dan melakukan model Discovery Learning. Dalam rancangan penelitian tersebut dapat dilihat perbedaan kemampuan berpikir kreatif siswa sebelum diterapkan model Discovery Learning dan sesudah diterapkan model Discovery Learning.

$\begin{array}{llll}\text { Eksperimen } & \mathrm{O}_{1} & \mathrm{X} & \mathrm{O}_{2} \\ \text { Kontrol } & \mathrm{O}_{1} & - & \mathrm{O}_{2}\end{array}$

Populasi dalam penelitian ini adalah seluruh siswa kelas IV SDN Sutawangi II Kecamatan Jatiwangi tahun ajaran 2014/2015. Adapun sampel dalam penelitian ini terdiri dari dua kelas, satu kelas sebagai kelas eksperimen yaitu kelas IV.A terdapat 21 siswa dan satu kelas sebagai kelas kontrol yaitu IV.B terdapat 21 siswa. Teknik sampling dalam penelitian ini adalah sampling purposive. Pemilihan dari kelompok ini didasarkan atas ciri-ciri tertentu yang dipandang mempunyai sangkut paut dengan ciri-ciri populasi yang sudah diketahui sebelumnya. Pemilihan sampel berdasarkan tujuan penelitian dengan melihat nilai kelas hasil tugas ilmu pengetahuan alam dan pertimbangan guru karena kedua kelas tersebut memiliki kemampuan kognitif yang mendekati sama.

Instrumen yang digunakan dalam penelitian ini berupa instrumen tes untuk mengukur kemampuan berpikir kreatif. Tes ini terdiri dari 10 butir essay. Tujuan dari penyusunan soal-soal ini adalah untuk mengukur kemampuan berpikir lancar (fluency),keluwesan (flexibility),keaslian (originality), dan elaborasi (elaboration).

\section{Hasil Penelitian}

Berdasarkan hasil analisis data yang diperoleh peneliti terhadap data pretest kelas eksperimen dan kelas kontrol dengan menggunakan uji-t menunjukkan bahwa kemampuan berpikir kreatif awal siswa pada kedua kelas tidak berbeda secara signifikan. Dengan demikian dapat dikatakan bahwa kemampuan awal siswa pada kedua kelas adalah sama. Pada data pretest kelas eksperimen maupun kontrol 
banyak siswa yang termasuk ke dalam kategori berpikir kreatif sangat rendah. Hal ini menunjukkan bahwa sebelumnya kemampuan berpikir kreatif siswa kurang dilatih oleh guru.

Berdasarkan hasil pengolahan data posttest, didapatkan bahwa terdapat perbedaan kemampuan berpikir kreatif yang signifikan setelah penerapan model discovery learning pada kelas eksperimen dengan metode diskusi biasa pada kelas kontrol. Pada kelas eksperimen siswa telah mencapai nilai KKM (Kriteria Ketuntasan Minimal), dengan nilai rata-rata posttest kelas eksperimen berjumlah 21 orang sebesar 75,52, sedangkan rata-rata nilai kelas kontrol dengan jumlah siswa 21 orang sebesar 64,71 dengan perbedaan rata-rata skor posttest sebesar 10,81. Hal ini menunjukkan adanya pengaruh penggunaan model discovery learning terhadap kemampuan berpikir kreatif siswa dengan konsep energi dan perubahannya.

Nilai LKS dalam aspek struktur kalimat mengalami peningkatan, sehingga kemampuan siswa membuat soal juga mengalami peningkatan. Hal ini dikarenakan pada pertemuan pertama siswa belum terbiasa belajar dalam berkelompok sehingga siswa kurang berkoordinasi secara baik dalam kelompoknya. Siswa belum terbiasa dalam membuat soal yang baik, misalnya siswa tidak menggunakan kata tanya dalam soal yang dibuatnya dan struktur bahasa kalimat soal belum sesuai dengan kaidah Bahasa Indonesia yang benar. Namun, pertemuan selanjutnya sudah diantisipasi guru dengan memberikan motivasi agar siswa dapat bekerja sama dengan kelompoknya.

Dalam pembelajaran ilmu pengetahuan alam menggunakan model discovery learning melibatkan secara maksimal seluruh kemampuan peserta didik untuk mencari dan menyelediki secara sistematis, kritis dan kreatif serta logis sehingga mereka dapat menemukan sendiri pengetahuan, sikap, dan keterampilan sebagai wujud adanya perubahan tingkah laku.

Model discovery learning diartikan sebagai prosedur mengajar yang mementingkan pengajaran seseorang, memanipulasi objek sebelum sampai ke generalisasi. Dengan teknik ini siswa dibiarkan menemukan sendiri atau mengalami proses mental sendiri, guru hanya membimbing dan memberikan instruksi. Sehingga pembelajaran melibatkan siswa dalam proses kegiatan mental melalui tukar pendapat, dengan berdiskusi, membaca sendiri dan mencoba sendiri, agar anak dapat belajar sendiri. Hal ini menunjukkan bahwa model discovery learning dapat membuat siswa lebih kreatif dalam pembelajaran, siswa mendapatkan pengalaman baru dalam belajar.

\section{Kesimpulan}

Terdapat perbedaan yang signifikan kemampuan berfikir kreatif siswa antara yang memperoleh model discovery learning dengan yang memperoleh pembelajaran konvensional. Dengan demikian model discovery learning berpengaruh secara signifikan terhadap kemampuan berpikir kreatif siswa.

\section{Daftar Pustaka}

Ahmadi, L.K. (2011). Mengembangkan Pembelajaran IPS Terpadu. Jakarta: PT Prestasi Pustakaraya.

Ali, M. (2009). Ilmu dan Aplikasi Pendidikan Bagian III Pendidikan Disiplin Ilmu. PT Imperial Bhakti Utama: Bandung.

Danim, S. (2010). Perkembangan Peserta didik. Bandung: Alfabeta Bandung.

Idrus, M. (2009). Metode Penelitian Ilmu Sosial Pendekatan Kualitatif dan 
Erlangga.

Kuantitatif. Yogyakarta:

Khoiri, W. (2013). Implementasi Model

Problem Based Learning

Berbantuan Multimedia Untuk

Meningkatkan Kemampuan

Berpikir Kreatif Siswa Kelas VII

Smp Negeri 4 Kudus Pada

Materi Segitiga. Skripsi Sarjana

Universitas Negeri Semarang.

Majid, A. (2009). Perencanaan

Pembelajaran Mengembangkan Standar Kompetensi Guru. PT Remaja Rosdakarya: Bandung.

Ormrod, J.E. (2008). Psikologi Pendidikan Membantu Siswa Tumbuh dan Berkembang. Jakarta: Erlangga.

Permadi, D. (2011). Bagaimana Mengembangkan Kecerdasan? (Metode Baru Untuk Mengoptimalkan Fungsi Otak Manusia). PT Sarana Panca Karya Nusa: Bandung.

Rasyid, A. (2011). Penilaian Hasil Belajar. CV Wacana prima: Bandung.

Nahdi, Dede Salim (2015). Meningkatkan Kemampuan Berpikir Kritis Dan Penalaran Matematis Siswa Melalui Model Brain Based Learning. Jurnal Cakrawala Pendas. Vol 3 No. 1 hal 13-22.
Sani, R. A. (2014). Pembelajaran Saintifik Untuk Implementasi Kurikulum 2013. Jakarta: Bumi Aksara.

Selan, Y. (2015). Peningkatan Model Pembelajaran IPS Melalui Model Discovery Learning Dengan Media Audio Visual Pada Siswa Kelas IV B SDN Kembangarum $01 \quad$ Kota Semarang. Skripsi Sarjana Universitas Negeri Semarang.

Solso, R.L. 2007. Psikologi Pendidikan. Jakarta. Erlangga

Sudarma, M. (2013). Mengembangkan Keterampilan Berpikir Kreatif. Jakarta: Raja Grafindo Persada.

Sugiyono. (2006). Statistika Untuk Penelitian. Bandung: ALFABETA

Sumiati. (2011). Metode Pembelajaran. Bandung: CV WACANA PRIMA

Supranto, 2009. Statistik Teori dan Aplikasi. Jakarta: Erlangga.

Susanto, A. (2013). Teori Belajar Dan Pembelajaran Di Sekolah Dasar. Jakarta: Prenada Media Group.

Wiratna, S. (2014). SPSS Untuk Penelitian. Yogyakarta: Pustaka Baru Press. 